\title{
Age of volcanism and its migration in the Samoa Islands
}

\author{
IAN MCDOUGALL* \\ Research School of Earth Sciences, The Australian National University, Canberra, ACT 0200, Australia
}

(Received 25 August 2009; accepted 9 December 2009; First published online 10 February 2010)

\begin{abstract}
Potassium-argon (K-Ar) ages on whole rock samples have been measured on lavas from the subaerial Samoa Islands, which form a broadly linear volcanic chain that extends from the ESE to the WNW for about $360 \mathrm{~km}$. The Manu'a Islands near the southeast limit of the chain exhibit youthful ages, with most $<0.4 \mathrm{Ma}$, in keeping with the geological observations. Tutuila consists of several volcanoes, and previous work yielded a mean $\mathrm{K}-\mathrm{Ar}$ age of $1.26 \pm 0.15 \mathrm{Ma}$ for the shield-building volcanism. Upolu, to the WNW of Tutuila, gives a mean age of $2.15 \pm 0.35 \mathrm{Ma}$ for the shield-building phase, represented by the Fagaloa Volcanics, with much of the island covered by significantly younger volcanic rocks. Savai'i, further to the WNW, is dominated by youthful volcanism, extending into historic times. In a restricted area, adjacent to the NE coast of Savai'i, previously thought to have volcanic rocks correlating with the Fagaloa Volcanics of Upolu, the ages are much younger than those on Upolu, lying between 0.32 and $0.42 \mathrm{Ma}$. Considering only the subaerial volcanism from Ta'u to Upolu, but also including Vailulu'u, the volcanism has migrated in a systematic ESE direction at $130 \pm 8 \mathrm{~mm} \mathrm{a}^{-1}$ over $300 \mathrm{~km}$ in the last $2.2 \mathrm{Ma}$. This rate is nearly twice that obtained from GPS measurements of Pacific Plate motion of $72 \mathrm{~mm} \mathrm{a}^{-1}$ at N64 $\mathrm{W}$ in this area. However, if the much older age of shield-building volcanism from the submarine foundations of Savai'i is included, the regression yields a volcanic migration rate of $72 \pm 14 \mathrm{~mm} \mathrm{a}^{-1}$, in keeping with the measured GPS rate and consistent with a hotspot origin for the island chain. This suggests that the volcanic migration rates determined from the age of subaerial volcanism can be considerably overestimated, and this is now evident in other Pacific Ocean island chains. Clearly, the ages of the main shield-building volcanism from subaerial volcanism are minima, and if the older submarine lavas can be measured, these may yield a migration rate more in keeping with current plate motions.
\end{abstract}

Keywords: K-Ar dating, hotspots, Samoa Islands, volcanism.

\section{Introduction}

The Samoa Islands extend over more than $350 \mathrm{~km}$ from ESE to WNW in the central Pacific Ocean (Fig. 1), and are situated at about latitude $14^{\circ} \mathrm{S}$ and between longitudes $169^{\circ}$ and $173^{\circ} \mathrm{W}$. The subaerial islands form two parallel segments of a broadly linear volcanic chain, offset by about $50 \mathrm{~km}$ from one another. The islands are built predominantly by basaltic volcanism on the Pacific Plate from seafloor more than $4000 \mathrm{~m}$ deep. GPS measurements indicate that the Pacific Plate in the Samoan region is currently moving at about $72 \mathrm{~mm} \mathrm{a}^{-1}$ at $\mathrm{N} 64^{\circ} \mathrm{W}$ (Beavan et al. 2002), and the trend of the island chain is subparallel to this plate motion. Toward the eastern end of the chain lie the Manu'a Islands, comprising Ta'u, Olosega and Ofu, which are remnants of relatively youthful basaltic volcanoes, as has long been recognized (Friedländer, 1910; Daly, 1924; Stearns, 1944; Stice \& McCoy, 1968). Tutuila is an essentially extinct and heavily eroded volcanic island (Stearns, 1944), mainly active between about 1.5 and 1.0 Ma ago (McDougall, 1985). Further to the WNW lie the very much larger volcanic islands of Upolu and Savai'i, displaying relatively youthful volcanism in part covering older volcanics on Upolu (Friedländer, 1910; Thomson, 1921; Stearns,

*E-mail: Ian.McDougall@anu.edu.au
1944; Kear \& Wood, 1959), and the landscape of Savai'i is dominated by youthful, even historic volcanism (Jensen, 1907). An active undersea volcano, Vailulu'u, was discovered relatively recently to the east of the Manu'a Islands at $169^{\circ} 03.5^{\prime} \mathrm{W}, 14^{\circ} 12.9^{\prime} \mathrm{S}$ (Hart et al. 2000).

The Samoan island chain is essentially parallel to a number of other island chains on the Pacific Plate, including the Hawaiian, Society and Austral chains, in which the volcanism has migrated progressively to the ESE with time in a regular manner, giving rise to the hotspot or plume hypothesis for their origin (Wilson, 1963; Morgan, 1971). Under these models the linear volcanic chains are the manifestation of volcanism emanating from a hotspot or plume source lying within the mantle below the moving rigid crustal plate. As the Pacific Plate moves to the WNW over a hotspot source, a volcanic island chain develops on the plate and shows a progressive younging to the ESE.

Although the Samoan chain has often been likened to the other Pacific island chains, the very youthful volcanism evident on Upolu and especially on Savai'i (Dana, 1849; Chubb, 1957) has placed in question the origin of the chain, with Chubb (1957) commenting that the pattern of volcanic migration in Samoa is opposite to that found elsewhere in the Pacific. As Rose Islet (also variously known as Rose Island or Rose Atoll), a coral atoll about $150 \mathrm{~km}$ ESE of the 


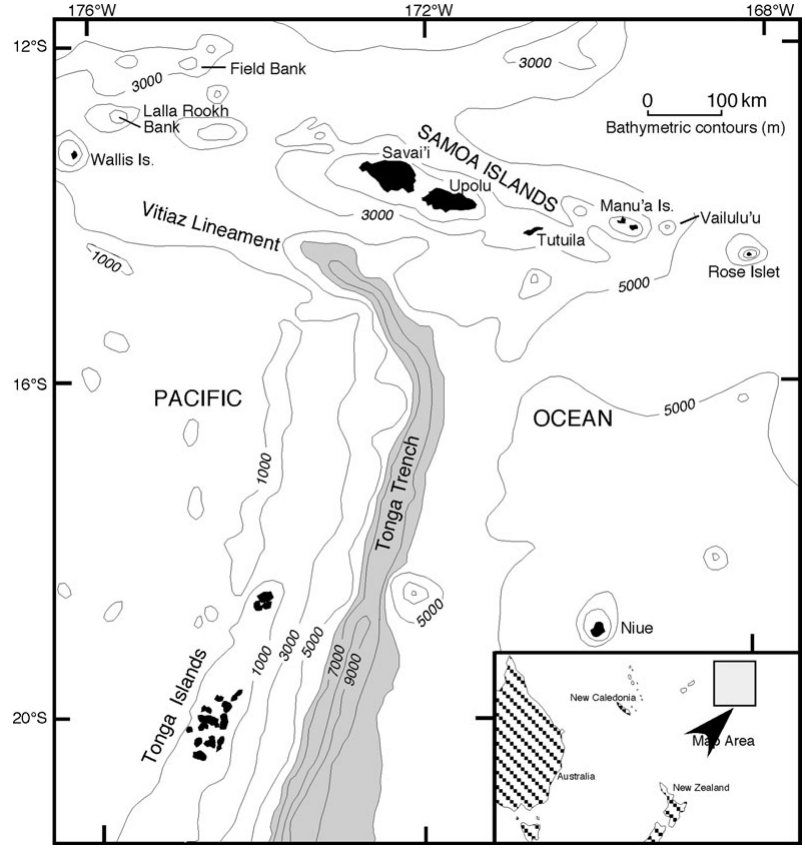

Figure 1. Location map of the Samoa Islands, also showing the generalized bathymetry. Combe Bank and Alexa Bank are not shown as they are located further WNW of the Samoa Islands; for actual locations see text.

Manu'a Islands (Fig. 1), was previously regarded as part of the Samoan chain, this reverse pattern of ageing was further reinforced. Hawkins \& Natland (1975) and Natland (1980) subsequently suggested that the volcanism, especially the voluminous, young, posterosional eruptive activity on Upolu and Savai'i, was more related to flexure of the Pacific Plate as a result of the proximity to the boundary with the Australian Plate marked by the Tonga Trench overlying a major subduction zone, that terminates just to the south of the Samoan Islands, where it turns nearly east-west and is known as the Vitiaz Lineament (Fig. 1). Of particular note is that Koppers et al. (2008) showed that samples dredged from the deep submarine flanks of Savai'i yield very much older ages than found for the youthful volcanism that dominates the island. These ${ }^{40} \mathrm{Ar}-{ }^{39} \mathrm{Ar}$ ages on samples from depths of more than $2500 \mathrm{~m}$ range from $4.10 \pm 0.11$ to $5.02 \pm 0.03 \mathrm{Ma}$, yielding ages that are much more consistent with a hotspot model for the Samoan volcanism.

Hart et al. (2000) in describing the submarine active volcano, Vailulu'u, to the east of Ta'u, concluded that the seamount is situated above the current location of the Samoan hotspot, and by implication Rose Islet is a quite separate edifice from the Samoan Island chain (see also Workman et al. 2004). Seismic tomography indicates the presence of a deep thermal plume beneath the eastern part of the Samoa Island chain (Montelli et al. 2004), consistent with a plume model for the origin of this volcanic island chain. A useful summary of the geology of the Samoa Islands is given by Keating (1992).
Because of the relative paucity of definitive age information on the volcanics of the Samoan chain, sampling was carried out on the subaerial islands of Samoa for $\mathrm{K}-\mathrm{Ar}$ dating purposes. Apart from elucidating the volcanic history of the individual islands, the main aim was to provide relevant information on the migration history of the main shieldbuilding volcanism, especially in relation to the hotspot hypothesis.

Some $\mathrm{K}-\mathrm{Ar}$ results were provided by Matsuda $\mathrm{et}$ al. (1984) for Upolu, but with no location details, so these results are not further discussed. Natland \& Turner (1985) provided a number of $\mathrm{K}-\mathrm{Ar}$ ages for Tutuila and Upolu, Workman et al. (2004) reported several ${ }^{40} \mathrm{Ar}-{ }^{39} \mathrm{Ar}$ ages from Upolu and Savai'i, and McDougall (1985) presented much $\mathrm{K}-\mathrm{Ar}$ data for Tutuila. Duncan (1985) measured $\mathrm{K}-\mathrm{Ar}$ and ${ }^{40} \mathrm{Ar}-$ ${ }^{39} \mathrm{Ar}$ ages on dredged samples from several seamounts to the WNW of Savai' $i$, and on the basis of these results suggested that some were part of the Samoan hotspot trace showing an average migration rate of the volcanism of $77 \pm 25 \mathrm{~mm} \mathrm{a}^{-1}$ to the ESE. Hart et al. (2004) reported additional ${ }^{40} \mathrm{Ar}-{ }^{39} \mathrm{Ar}$ age data from several of the same seamounts.

Geochemically, lavas of the Samoan Islands have distinctive isotopic and trace element characteristics of an enriched mantle (EM2) source region (Hart et al. 2004; Workman et al. 2004; see also Wright \& White, 1986/87). Similar characteristics are found for some dredged samples from Lalla Rookh, Combe and Alexa seamounts, regarded as also related to the Samoan hotspot trail (Duncan, 1985; Hart et al. 2004), and Jackson et al. (2007) reported even more geochemically enriched samples from dredged material on the flanks of Savai'i. Alkali basalts are dominant, especially among lavas regarded as erupting well after the main shield-building interval, and are often referred to as 'post-erosional'. However, lavas considered to belong to the shield-building phase in some cases show tholeiitic to transitional major element compositions (Natland \& Turner, 1985).

Politically, the islands of Upolu and Savai'i comprise the independent state of Samoa, whereas Tutuila and the Manu'a Islands are the main islands of American Samoa.

\section{Analytical methods}

Samples were collected from the densest parts of the least weathered lava flows using a sledge hammer, in most cases from outcrop. Each sample was subsequently thin-sectioned and examined under a petrographic microscope. Only those samples essentially free of alteration, and which were holocrystalline, or had less than $5 \%$ interstitial mesostasis or volcanic glass, were accepted as suitable for $\mathrm{K}-\mathrm{Ar}$ dating. Samples were crushed to a fragment size of 0.25 to $0.6 \mathrm{~mm}$, and where there was a significant phenocrystic component, usually olivine, heavy liquids were used to separate it and the remainder used for analysis, to 


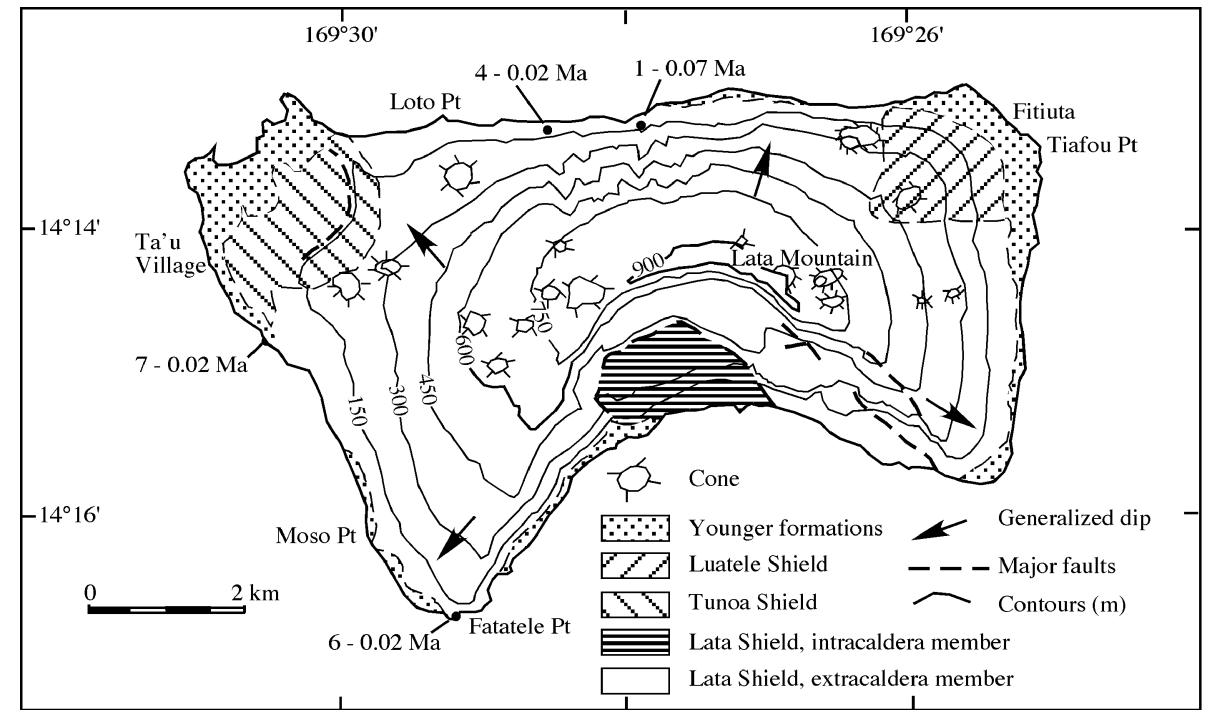

Figure 2. Geology of Ta'u, after Stice \& McCoy (1968), showing the location and age of samples that were K-Ar dated. Full results are listed in Table 1.

minimize the risk of excess argon and unrealistically old ages. Techniques of $\mathrm{K}-\mathrm{Ar}$ measurement have been described previously (McDougall \& Feibel, 1999), with potassium determined in duplicate by flame photometry and argon measured, after fusion of an aliquot of the sample in an ultrahigh vacuum system, by isotope dilution using $\mathrm{a}^{38} \mathrm{Ar}$ tracer. The uncertainties in the separate measurements of potassium and radiogenic argon generally were less than $1 \%$, except in those cases where the proportion of radiogenic argon was less than $5 \%$, when greater errors were found. The $\mathrm{K}-\mathrm{Ar}$ data are listed in Tables 1 to 3, where the uncertainties in the calculated ages are given at the level of one standard deviation. All ages are calculated using the ${ }^{40} \mathrm{~K}$ decay constants and abundance recommended by Steiger \& Jäger (1977).

The calculated ages are taken at face value, recognizing that in many cases it is not possible to evaluate separately whether problems with excess argon, leading to older apparent ages, or loss of radiogenic argon, resulting in ages younger than the eruptive age, are evident. However, the overall consistency of the ages from individual volcanoes suggests that in most cases the assumptions made in calculating an age are valid.

For information, the numerical time scale adopted here is that from Gradstein, Ogg \& Smith (2004), in which the Pliocene-Pleistocene boundary is given as $1.81 \mathrm{Ma}$, the base of the Middle Pleistocene as $0.78 \mathrm{Ma}$ (the boundary between the Brunhes and Matuyama chrons), and the base of the Upper Pleistocene is estimated to be at $0.13 \mathrm{Ma}$.

\section{Manu'a Islands}

The Manu'a Islands, a group of three volcanic islands Ta'u, Olosega and Ofu, lie about $100 \mathrm{~km}$ east of Tutuila (Fig. 1), and about $45 \mathrm{~km}$ west of the active submarine volcano of Vailulu'u (Hart et al. 2000). They clearly are remnants of quite youthful volcanoes that have lost parts of their structures owing to major collapse, as well recognized by many workers (Friedländer, 1910; Daly, 1924; Stearns, 1944; Stice \& McCoy, 1968).

Ta'u consists mainly of the Lata shield volcano, which has a well-preserved constructional shape, and is built by basaltic lava flows and pyroclastics emanating from rifts associated with the general summit region which reaches an altitude of just over $960 \mathrm{~m}$. A caldera, partly filled, lies immediately to the south of Lata Mountain (Stice \& McCoy, 1968). The southern part of the volcano has been lost, presumably by gravitational collapse, revealing spectacular cliffs (Fig. 2). Smaller, younger stuctures, the Luatele shield volcano, and the Tunoa shield volcano, have developed at the northeast and northwest extremities of Ta'u, respectively, and there are many small young cones dotting the Lata shield (Fig. 2), as described by Stice \& McCoy (1968). In Figure 2 and subsequent figures showing the measured age of individual samples, the number given before the age is the original field designation shown in the tables without the prefix. In the text the laboratory number is usually given with the abbreviated field number shown in parentheses.

Stice \& McCoy (1968) suggested that the earliest eruptions might have occurred in Late Pliocene or Early Pleistocene time, but all workers recognized that much of the surface of the main shield volcano was constructional with relatively little dissection, and thus both the surface of the volcano and indeed the whole edifice are probably very young. Stice \& McCoy (1968) regarded lavas adjacent to the north coast, mapped as belonging to the extracaldera member of the Lata Formation of the Lata shield volcano, as among the oldest exposed, and probably pre-caldera in age.

Several samples of basalt were collected from lava flows adjacent to the north coast and from the southwest coast for possible $\mathrm{K}-\mathrm{Ar}$ dating. All four samples that were analysed yielded very youthful ages of $<0.1 \mathrm{Ma}$ (Table 1). The proportion of radiogenic argon was less 
Table 1. Potassium-argon ages on whole rock basalt samples from Manu'a Islands, American Samoa

\begin{tabular}{|c|c|c|c|c|c|c|c|c|}
\hline $\begin{array}{l}\text { Sample } \\
\text { number }\end{array}$ & $\begin{array}{c}\text { Field } \\
\text { number }\end{array}$ & K wt \% & $\begin{array}{c}{ }^{40} \mathrm{Ar}^{*} \\
10^{-13} \mathrm{~mol} / \mathrm{g}\end{array}$ & $\begin{array}{c}\% \\
{ }^{40} \mathrm{Ar}^{*}\end{array}$ & $\begin{array}{l}\text { Calculated age } \\
\text { Ma } \pm 1 \text { s.d. }\end{array}$ & Latitude S & Longitude W & Locality \\
\hline \multicolumn{9}{|c|}{ Ta'u Island, Lata Formation } \\
\hline $82-230$ & MA7 & $0.805,0.806$ & $<0.2$ & 0.0 & $<0.02$ & $14^{\circ} 14^{\prime} 28^{\prime \prime}$ & $169^{\circ} 30^{\prime} 34^{\prime \prime}$ & Vaitele Point, $\sim 1 \mathrm{~m}$ thick lava \\
\hline $82-227$ & MA4 & $0.819,0.819$ & 0.263 & 0.2 & $0.02 \pm 0.02$ & $14^{\circ} 13^{\prime} 00^{\prime \prime}$ & $169^{\circ} 28^{\prime} 38^{\prime \prime}$ & Near $N$ coast, $\sim 3 \mathrm{~m}$ thick lava \\
\hline $82-224$ & MA1 & $0.677,0.678$ & 0.829 & 1.7 & $0.07 \pm 0.01$ & $14^{\circ} 12^{\prime} 56^{\prime \prime}$ & $169^{\circ} 27^{\prime} 56^{\prime \prime}$ & $\mathrm{N}$ coast, Avatele Stream, $8 \mathrm{~m}$ lava \\
\hline $82-229$ & MA6 & $0.805,0.799$ & 0.314 & 1.0 & $0.02 \pm 0.01$ & $14^{\circ} 16^{\prime} 21^{\prime \prime}$ & $169^{\circ} 29^{\prime} 15^{\prime \prime}$ & Fatatele Point, thin flow \\
\hline \multicolumn{9}{|c|}{ Olosega Island, Tuafanua Formation } \\
\hline \multirow[t]{2}{*}{$82-233$} & MA10 & $1.189,1.196$ & 4.97 & 13.1 & $0.24 \pm 0.01$ & $14^{\circ} 09^{\prime} 37^{\prime \prime}$ & $169^{\circ} 37^{\prime} 02^{\prime \prime}$ & Boulder, foot of cliff, near $\mathrm{N}$ tip \\
\hline & & & 5.08 & 13.3 & $0.25 \pm 0.01$ & & & \\
\hline \multirow[t]{2}{*}{$82-232$} & MA9 & $0.887,0.888$ & 6.46 & 16.9 & $0.42 \pm 0.01$ & $14^{\circ} 09^{\prime} 30^{\prime \prime}$ & $169^{\circ} 36^{\prime} 59^{\prime \prime}$ & Boulder, foot of cliff, near $\mathrm{N}$ tip \\
\hline & & & 6.73 & 14.8 & $0.44 \pm 0.01$ & & & \\
\hline \multicolumn{9}{|c|}{ Ofu Island, Tuafanua Formation } \\
\hline $82-235$ & MA12 & $1.005,1.008$ & 4.26 & 12.3 & $0.24 \pm 0.01$ & $14^{\circ} 09^{\prime} 50^{\prime \prime}$ & $169^{\circ} 40^{\prime} 06^{\prime \prime}$ & Near N coast, Sinapoto, $\sim 1 \mathrm{~m}$ flow \\
\hline $82-236$ & MA13 & $1.044,1.049$ & 4.59 & 15.7 & $0.25 \pm 0.01$ & $14^{\circ} 09^{\prime} 50^{\prime \prime}$ & $169^{\circ} 40^{\prime} 06^{\prime \prime}$ & Near $\mathrm{N}$ coast, Sinapoto, $\sim 3 \mathrm{~m}$ flow \\
\hline $82-239$ & MA16 & $1.090,1.094$ & 5.82 & 10.0 & $0.31 \pm 0.01$ & $14^{\circ} 09^{\prime} 40^{\prime \prime}$ & $169^{\circ} 40^{\prime} 52^{\prime \prime}$ & Tauga Point, $\sim 5 \mathrm{~m}$ thick flow \\
\hline $82-240$ & MA17 & $1.096,1.096$ & 7.59 & 10.1 & $0.40 \pm 0.01$ & $14^{\circ} 09^{\prime} 40^{\prime \prime}$ & $169^{\circ} 40^{\prime} 52^{\prime \prime}$ & Tauga Point, $\sim 2 \mathrm{~m}$ thick flow \\
\hline $82-242$ & MA19 & $1.472,1.479$ & 8.24 & 21.4 & $0.32 \pm 0.01$ & $14^{\circ} 10^{\prime} 35^{\prime \prime}$ & $169^{\circ} 40^{\prime} 39^{\prime \prime}$ & West coast, $\sim 3 \mathrm{~m}$ aphyric flow \\
\hline
\end{tabular}

$\lambda_{\mathrm{e}}=0.581 \times 10^{-10} \mathrm{a}^{-1} ; \lambda_{\beta}=4.962 \times 10^{-10} \mathrm{a}^{-1} ;{ }^{40} \mathrm{~K} / \mathrm{K}=1.167 \times 10^{-4} \mathrm{~mol} / \mathrm{mol}$

${ }^{40} \mathrm{Ar}^{*}$ - radiogenic argon; coordinates for locations derived from Google Earth images

Phenocrystic olivine and, if present, clinopyroxene, removed from each sample, except for samples MA16, MA17 and MA19, which were aphyric.

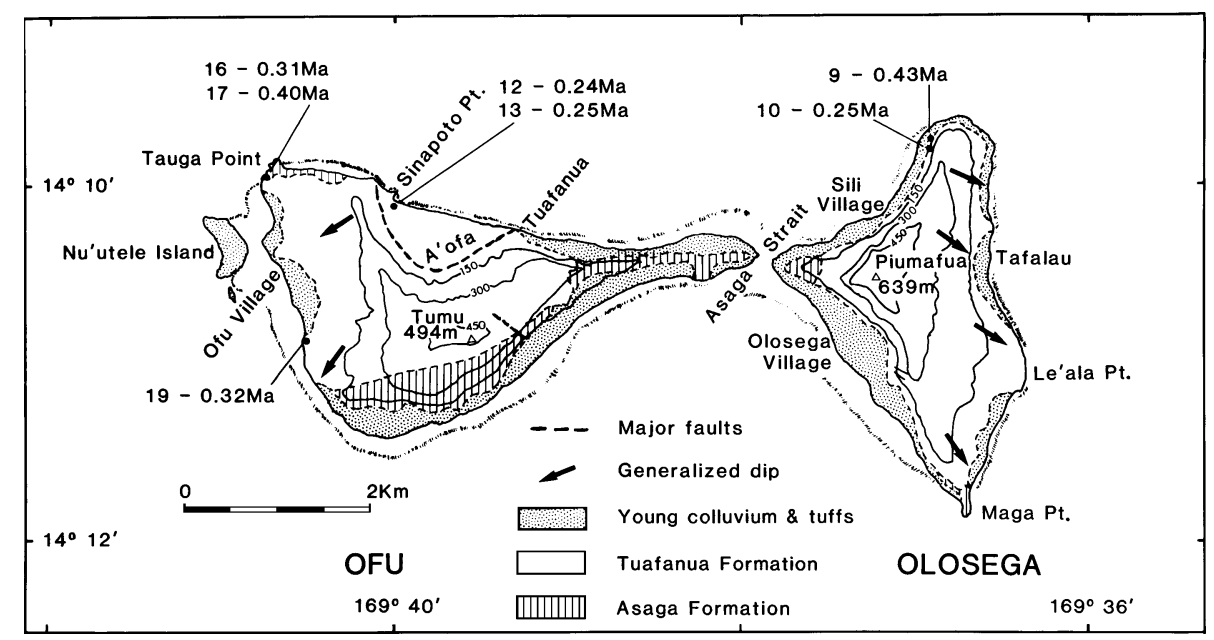

Figure 3. Geology of Olosega and Ofu, after Stice \& McCoy (1968), showing the location and measured age of samples dated. Results are listed in Table 1.

than $2 \%$ in all cases, so that the ages are imprecise. Samples 82-229 ((6) in Fig. 2) from Fatatele Point on the south coast, and 82-224 (1) from adjacent to the north coast, are thought to be pre-caldera in age. They yield the oldest apparent ages, but are less than $0.1 \mathrm{Ma}$. The other two samples (82-227 (4), 82-230 (7)) are thought to be post-caldera in age, and are indeed very youthful at $\leq 0.02 \mathrm{Ma}$. Overall, the ages are fully consistent with the preserved constructional form of the island and the very limited erosion, despite the tropical climate and high rainfall, amply confirming that the volcanism is indeed very youthful, Late Pleistocene or younger. It is suggested that an average age of say $0.05 \mathrm{Ma}$ for the main subaerial shield-building stage for Ta'u is a reasonable estimate. The extremely young ages found are also important in providing confidence that these rocks do not carry significant excess argon.

Olosega and Ofu are twin volcanic islands with the narrow Asaga Strait (Fig. 3) between them, and they are separated from Ta'u by a little over $10 \mathrm{~km}$ of water that is less than 200 m deep. Friedländer (1910), Daly (1924) and Stearns (1944) each concluded that the two islands are closely related edifices, and the more detailed mapping by Stice \& McCoy (1968) elaborates on the earlier work. The essentially radial generalized dips of the basaltic lavas and pyroclastics that have built the islands, shown in Figure 3, after Stice \& McCoy (1968), could well be interpreted to be the result of eruption from a single volcano, whose centre was located to the north of both islands. All workers recognized that the islands are but erosional remnants of a much larger overall edifice, whether this be a single entity or two coalescing shields, and that gravitational collapse has played a major role in the present configuration of the subaerially preserved islands. Stice \& McCoy (1968) showed that lavas in the A'ofa area of northern Ofu are caldera filling. Together, the two islands extend over nearly $9 \mathrm{~km}$ (east-west) and 2 to $4 \mathrm{~km}$ (north-south), rising to $494 \mathrm{~m}$ on Ofu and $639 \mathrm{~m}$ on Olosega. Both islands have been extensively 
cliffed by marine erosion, and each has a fringing coral reef.

Stice \& McCoy (1968) mapped the Asaga Formation as among the oldest rocks exposed, consisting of basaltic pyroclastics and intrusives that are best displayed on Ofu. The Tuafanua Formation was the name given to the products of the main shield-building phase of interbedded basaltic lavas and pyroclastics, comprising much of the outcrop on both islands (Fig. 3). Dips commonly are $10-20^{\circ}$, but lavas in the A'ofa caldera are nearly horizontal.

Two samples were collected for dating from Olosega, near its northern tip, and these were from boulders, because of the difficulty of obtaining samples in situ, owing to the heavy vegetation and difficulties of access. However, both samples are considered to be derived locally from the cliff above. Measured $\mathrm{K}-\mathrm{Ar}$ ages are reproducible (Table 1) but are different from one another at about $0.24 \pm 0.01 \mathrm{Ma}$ and $0.43 \pm 0.01 \mathrm{Ma}$, with more than $10 \%$ radiogenic argon identified in each analysis. This large age difference was unexpected, but perhaps the younger age is from an intrusive body. Alternatively, the older apparent age may reflect the presence of excess radiogenic argon, but this is unproven.

For Ofu, two flows from the shield-building lavas at Tauga Point, at the northwest tip of the island, yielded apparent ages of $0.40 \pm 0.01(82-240(17))$ and $0.31 \pm 0.01 \mathrm{Ma}(82-239$ (16)), with sample 82-239 from a near aphyric lava flow about $5 \mathrm{~m}$ thick, whereas sample 82-240 was from a block thought to derive from a thinner flow about two flows above that from which 82-239 was obtained. Thus, the apparent ages are seemingly inconsistent with the stratigraphy, again posing a problem. Sample 82-242 (19, Fig. 3) is from an aphyric hawaiite lava flow from a section about $20 \mathrm{~m}$ high in a cliff and road cut, adjacent to the southwest coast. An age of $0.32 \pm 0.01 \mathrm{Ma}$ was obtained (Table 1) with over $20 \%$ of the argon radiogenic. As this age is similar to those found from Tauga Point it seems likely that the lava is also from the main shield-building phase, the Tuafanua Formation. Two samples from essentially horizontal aphyric lavas, exposed on either side of a gully at Sinapoto in the intracaldera member of the Tuafanua Formation, yielded ages in good agreement at $0.24-0.25 \mathrm{Ma}$ (Table 1 ). These slightly younger ages are consistent with one another, giving confidence in their veracity, noting that the ages are younger than those determined on extracaldera lavas.

Although there are some unexplained inconsistencies in the measured ages from the samples from Olosega and Ofu, all the results lie in the relatively narrow range of 0.44 to $0.24 \mathrm{Ma}$. The seven ages average $0.31 \pm 0.08 \mathrm{Ma}$, which is taken as the best estimate for the shield-building phase of Ofu and Olosega. This places the activity in the latter part of the Middle Pleistocene. The ages are consistent with the somewhat dissected nature of the islands, both remnants from major gravitational collapse of the much larger volcanic edifice that was formerly present.

\section{Tutuila}

Tutuila was built by a number of shield volcanoes (Stearns, 1944). An average age of $1.26 \pm 0.15 \mathrm{Ma}$ for the shield-building volcanism is derived from the 33 of the 38 age measurements reported by McDougall (1985), excluding only ages measured on the trachytes. Three K-Ar ages reported by Natland \& Turner (1985) from Tutuila lie between 1.03 and $1.40 \mathrm{Ma}$, entirely within the range measured by McDougall (1985).

\section{Upolu}

Upolu is a volcanic island nearly $80 \mathrm{~km}$ in length (WNW-ESE) and averaging a little over $20 \mathrm{~km}$ wide; it rises to an altitude of about $1100 \mathrm{~m}$. The backbone of the island, centrally located and parallel to the length of the island and striking about $110^{\circ}$, has numerous small youthful cones along it (Fig. 4). This is regarded as the major fracture zone from which many of the eruptions, predominantly basaltic, have emanated, producing the island (Kear \& Wood, 1959). Upolu is the emergent part of a much larger edifice built up from the deep ocean floor. Kear \& Wood (1959) named and mapped a number of volcanic formations, the oldest of which they called the Fagaloa Volcanics, a sequence of dominantly basaltic lava flows exposed mainly adjacent to the north coast, east of Apia, and in the southwest near Lefaga Bay (Fig. 4). Kear \& Wood (1959) and subsequent workers (e.g. Natland, 1980) clearly regarded the Fagaloa Volcanics as the main subaerial shield-building lavas, most of which are tholeiitic to mildly alkalic (Natland, 1980). The lavas generally have low dips, usually $10^{\circ}$, toward the sea, consistent with eruption from the main fracture zone. The area underlain by the Fagaloa Volcanics adjacent to the north coast has very rugged topography and is heavily vegetated. Subsequently, voluminous, post-erosional lavas, regarded as Middle Pleistocene or younger by Kear \& Wood (1959), were erupted and covered much of the topography developed on the Fagaloa Volcanics, except adjacent to the northeast coast. These posterosional lavas were identified and mapped by Kear \& Wood (1959) as the Salani, Mulifanua, Lefaga and Puapua volcanics of decreasing age. They are dominantly basaltic and alkalic (Natland, 1980), and have also been erupted mainly from the axial rift zone (Kear \& Wood, 1959). From the geomorphology and the relation of the volcanism to the fringing and barrier coral reefs, Kear \& Wood (1959) suggested that the earliest eruptions of the Salani Volcanics were probably no older that the penultimate glaciation, thus no older than about 0.2 Ma. Nevertheless, the Salani Volcanics have locally been quite deeply eroded with formation of deep, amphitheatre-headed canyons, which in places have been covered subsequently by Mulifanua Volcanics and younger lavas.

Natland (1980) and Natland \& Turner (1985) argued for the existence of a caldera in the Fagaloa Volcanics, centred on Fagaloa Bay on the northeast coast. The 


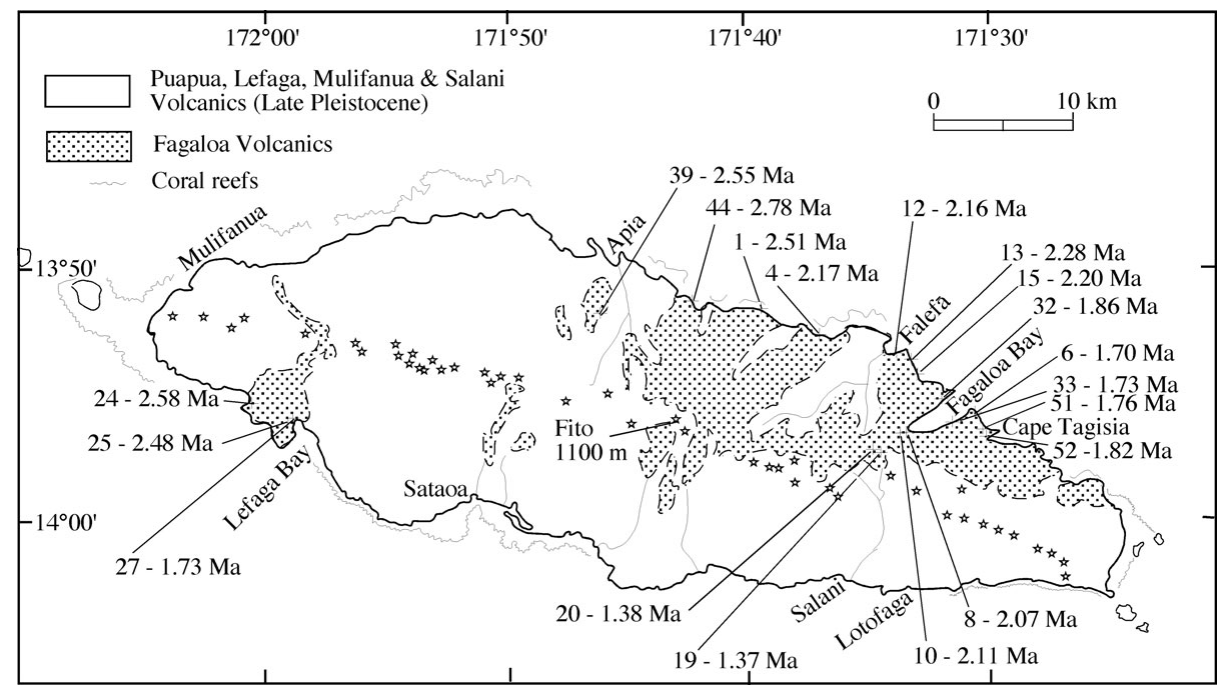

Figure 4. Simplified geology of Upolu, where the stars show the locations of relatively youthful centres of eruption, following Kear \& Wood (1959). The location of each dated sample and its K-Ar age are shown, with detailed results listed in Table 2.

caldera was about 10 by $5 \mathrm{~km}$ in size, with lavas preserved within it regarded as younger than the main Fagaloa shield volcano. The presence of more evolved lavas and intrusives, trachytes and mugearites, was quoted as strong supporting evidence. A $\mathrm{K}-\mathrm{Ar}$ age of $1.54 \pm 0.05 \mathrm{Ma}$ on a mugearite boulder from Ma'asina in Fagaloa Bay, younger than ages of 1.82 to $2.80 \mathrm{Ma}$ on four other lavas from the Fagaloa Volcanics (Natland \& Turner, 1985), was also regarded as good evidence for the existence of a caldera, as well as showing that the Fagaloa Volcanics were erupted in Late Pliocene to Early Pleistocene times.

Many samples for possible $\mathrm{K}$-Ar dating were collected from lava flows of the Fagaloa Volcanics, mainly from outcrops adjacent to the north coast. As commented on by previous workers, it is generally not possible to place samples within a regional shield volcano stratigraphy because of the marked erosion and the extensive vegetation cover.

The $\mathrm{K}-\mathrm{Ar}$ ages determined on samples that met the freshness and crystallinity criteria are listed in Table 2, approximately in order from oldest to youngest, except that where samples have been collected in close proximity the results are kept together. Thus, the results from three samples of basalt from the southwest coast between Sama'i and Lefaga Bay are listed together at the base of the table. In this area, no outcrops were found, so that the measurements were made on boulders weathering out of a clay matrix adjacent to the road (samples 82-95 (24), 82-96 (25)), whereas sample 8298 (27) was collected from a boulder in a creek bed near the head of Lefaga Bay. Both 82-95 and 8296 yielded relatively old measured ages, $2.58 \pm 0.03$ and $2.48 \pm 0.03 \mathrm{Ma}$, Late Pliocene. A rather younger age of $1.73 \pm 0.02 \mathrm{Ma}$ was obtained on sample 8298. Workman et al. (2004) reported ${ }^{40} \mathrm{Ar}-{ }^{39} \mathrm{Ar}$ ages on two samples from the same general area, listing them as from the A'ana Shield, yielding plateau ages of $0.93 \pm 0.01$ and $2.65 \pm 0.02 \mathrm{Ma}$. Owing to the lack of stratigraphic context it is not possible to say much about these ages except that there is evidence for the Fagaloa Volcanics having been erupted over an extensive interval exceeding 1.7 Ma. The 16 other $\mathrm{K}-\mathrm{Ar}$ results in Table 2 come from rocks collected from the region north of the axial rift zone. Mt Vaea, immediately to the south of Apia, consists of basalts assigned to the Fagaloa Volcanics surrounded by much younger Salani Volcanics (Kear \& Wood, 1959). A single basalt sample from this sequence (82-110 (39)), containing small phenocrysts of plagioclase and clinopyroxene, gave an age of $2.55 \pm 0.03 \mathrm{Ma}$. Natland \& Turner (1985) showed that four samples from the Mt Vaea sequence all have normative hypersthene and are therefore classified as tholeiites.

A number of samples from the Fagaloa Volcanics were collected adjacent to the road along the north coast, east of Apia. Sample 82-115 (44), from a cliff immediately west of Lauli'i, yielded the oldest age measured on Upolu of $2.78 \pm 0.03 \mathrm{Ma}$. A further $5 \mathrm{~km}$ to the east at Cape Utumau'u, a basalt $(82-72$ (1)) with abundant plagioclase phenocrysts as well as some phenocrysts of olivine and clinopyroxene, gave an age of $2.51 \pm 0.03 \mathrm{Ma}$. A clinopyroxene and olivine phyric lava (82-75 (4)) sampled from just east of Solosolo, about $4 \mathrm{~km}$ ESE of 82-72, yielded a significantly younger age of $2.17 \pm 0.02 \mathrm{Ma}$. Similar ages were found on a basalt just east of Falefā (8283 (12); $2.16 \pm 0.03 \mathrm{Ma}$ ) and on two samples from near Saugo, collected about $0.5 \mathrm{~km}$ apart, with ages of $2.28 \pm 0.02 \mathrm{Ma}(82-84(13))$ and $2.20 \pm 0.03 \mathrm{Ma}$ (82-86 (15)). Ages of 2.07 and $2.11 \mathrm{Ma}(82-79$ (8), 82-81 (10)) were measured on basalts from the road between Fagaloa Bay and Fagaloa Saddle; these are slightly younger but quite similar to those just discussed. Five samples from near Fagaloa Bay yielded distinctly younger ages of $1.86 \pm 0.02$ to $1.73 \pm 0.02 \mathrm{Ma}$ (samples 82-103 (32), -123 (52), $-122(51),-77(6),-104(33))$. The oldest apparent age from sample 82-103 was collected from an aphyric boulder below a cliff of essentially horizontal lava flows 
Table 2. Potassium-argon ages on mainly basalt whole rock samples from the Fagaloa Volcanics, Upolu, Western Samoa

\begin{tabular}{|c|c|c|c|c|c|c|c|c|}
\hline $\begin{array}{l}\text { Sample } \\
\text { number }\end{array}$ & $\begin{array}{l}\text { Field } \\
\text { number }\end{array}$ & K wt \% & $\begin{array}{c}{ }^{40} \mathrm{Ar}^{*} \\
10^{-12} \\
\mathrm{~mol} / \mathrm{g}\end{array}$ & $\%{ }^{40} \mathrm{Ar}^{*}$ & $\begin{array}{l}\text { Calculated age } \\
\mathrm{Ma} \pm 1 \text { s.d. }\end{array}$ & Latitude S & Longitude W & Locality \\
\hline $82-91$ & UP20 & $0.970,0.981$ & 2.332 & 25.9 & $1.38 \pm 0.02$ & $\sim 13^{\circ} 57^{\prime} 16^{\prime \prime}$ & $\sim 171^{\circ} 35^{\prime} 51^{\prime \prime}$ & $\begin{array}{l}\text { Near Le Mafa pass, } \sim 5 \mathrm{~m} \text { flow, } \\
\sim 265 \mathrm{~m} \text { asl }\end{array}$ \\
\hline $82-90$ & UP19 & $0.856,0.852$ & 2.035 & 28.7 & $1.37 \pm 0.02$ & $\sim 13^{\circ} 57^{\prime} 13^{\prime \prime}$ & $\sim 171^{\circ} 35^{\prime} 34^{\prime \prime}$ & $\begin{array}{l}\text { Road to Le Mafa, } \sim 5 \mathrm{~m} \text { flow, } \\
\sim 200 \mathrm{~m} \text { asl }\end{array}$ \\
\hline 82-104 & UP33 & $3.727,3.725$ & 11.180 & 64.6 & $1.73 \pm 0.02$ & $13^{\circ} 56^{\prime} 28^{\prime \prime}$ & $171^{\circ} 32^{\prime} 16^{\prime \prime}$ & $\begin{array}{l}\text { Ma'asina, S side Fagaloa Bay, } \\
\text { trachyte }\end{array}$ \\
\hline $82-77$ & UP6 & $1.491,1.487$ & 4.393 & 14.1 & $1.70 \pm 0.04$ & $13^{\circ} 56^{\prime} 01^{\prime \prime}$ & $171^{\circ} 31^{\prime} 40^{\prime \prime}$ & $\mathrm{S}$ of Fagaloa Bay, $\sim 75 \mathrm{~m}$ asl \\
\hline $82-122$ & UP51 & $1.086,1.079$ & 3.313 & 55.0 & $1.76=$ & $13^{\circ} 56^{\prime} 28^{\prime \prime}$ & $171^{\circ} 31^{\prime} 19^{\prime \prime}$ & $\begin{array}{l}\text { Near Cape Tagisia, } \sim 3 \mathrm{~m} \text { flow, } \\
\sim 125 \mathrm{~m} \text { asl }\end{array}$ \\
\hline $82-123$ & UP52 & $1.446,1.452$ & 4.583 & 64.2 & $1.82 \pm 0.02$ & $13^{\circ} 56^{\prime} 42^{\prime \prime}$ & $171^{\circ} 31^{\prime} 12^{\prime \prime}$ & $\begin{array}{l}\text { Near Cape Tagisia, } \sim 2 \mathrm{~m} \text { flow, } \\
\sim 125 \mathrm{~m} \text { asl }\end{array}$ \\
\hline $82-103$ & UP32 & $1.367,1.362$ & 4.394 & 43.9 & $1.86 \pm 0.02$ & $13^{\circ} 55^{\prime} 34^{\prime \prime}$ & $171^{\circ} 33^{\prime} 10^{\prime \prime}$ & N side Fagaloa Bay, under Fao \\
\hline $82-81$ & UP10 & $0.511,0.509$ & 1.866 & 24.0 & $2.11 \pm 0.03$ & $\sim 13^{\circ} 56^{\prime} 43^{\prime \prime}$ & $\sim 171^{\circ} 34^{\prime} 56^{\prime \prime}$ & $\begin{array}{l}\text { E of Fagaloa Saddle, } \sim 2 \mathrm{~m} \text { flow, } \\
\sim 170 \mathrm{~m} \text { asl }\end{array}$ \\
\hline $82-79$ & UP8 & $0.990,0.988$ & 3.543 & 40.9 & $2.07 \pm 0.02$ & $\sim 13^{\circ} 56^{\prime} 45^{\prime \prime}$ & $\sim 171^{\circ} 34^{\prime} 36^{\prime \prime}$ & $\begin{array}{l}\text { E of Fagaloa Saddle, thick flow, } \\
\sim 120 \mathrm{~m} \text { asl }\end{array}$ \\
\hline $82-86$ & UP15 & $0.738,0.744$ & 2.833 & 50.0 & $2.20 \pm 0.03$ & $13^{\circ} 54^{\prime} 24^{\prime \prime}$ & $171^{\circ} 33^{\prime} 56^{\prime \prime}$ & $\begin{array}{l}\mathrm{N} \text { coast, near Sauago, } \sim 3 \mathrm{~m} \text { flow, } \\
\sim 30 \mathrm{~m} \text { asl }\end{array}$ \\
\hline $82-84$ & UP13 & $0.951,0.947$ & 3.761 & 57.4 & $2.28 \pm 0.02$ & $13^{\circ} 54^{\prime} 04^{\prime \prime}$ & $171^{\circ} 34^{\prime} 03^{\prime \prime}$ & $\begin{array}{l}\mathrm{N} \text { coast, near Sauago } \sim 1 \mathrm{~m} \text { flow, } \\
\sim 40 \mathrm{~m} \text { asl }\end{array}$ \\
\hline $82-83$ & UP12 & $0.959,0.964$ & 3.601 & 39.2 & $2.16 \pm 0.03$ & $13^{\circ} 53^{\prime} 36^{\prime \prime}$ & $171^{\circ} 35^{\prime} 50^{\prime \prime}$ & $\begin{array}{l}\mathrm{N} \text { coast, } \mathrm{E} \text { of Falefā, } \sim 3 \mathrm{~m} \text { flow, } \\
\sim 20 \mathrm{~m} \text { asl }\end{array}$ \\
\hline $82-75$ & UP4 & $1.524,1.521$ & 5.746 & 54.1 & $2.17 \pm 0.02$ & $13^{\circ} 52^{\prime} 27^{\prime \prime}$ & $171^{\circ} 37^{\prime} 53^{\prime \prime}$ & $\begin{array}{l}1 \mathrm{~km} \mathrm{E} \text { of Solosolo, } \mathrm{N} \text { coast, } \sim 2 \mathrm{~m} \\
\text { flow }\end{array}$ \\
\hline $82-72$ & UP1 & 1.00 & 4.38 & 39. & 2. & $13^{\circ} 51$ & $171^{\circ} 3$ & Cape Utumau'u, $\mathrm{N}$ coast, $\sim 1 \mathrm{~m}$ flow \\
\hline $82-115$ & UP44 & $0.970,0.969$ & 4.680 & 52.2 & & $13^{\circ} 5$ & $171^{\circ} 42^{\prime} 39^{\prime \prime}$ & Near Lauli'i, $N$ coast \\
\hline $82-110$ & UP39 & $1.079,1.084$ & 4.787 & 34.6 & $2.55 \pm 0.03$ & $13^{\circ} 51^{\prime} 58^{\prime \prime}$ & $171^{\circ} 46^{\prime} 05^{\prime \prime}$ & $\begin{array}{l}\text { Slopes of Mt Vaea, S of Apia, } \\
\sim 250 \mathrm{~m} \text { asl }\end{array}$ \\
\hline $82-98$ & UP27 & $1.263,1.262$ & 3.793 & 57.0 & $1.73 \pm 0.02$ & $13^{\circ} 55^{\prime} 48^{\prime \prime}$ & $171^{\circ} 58^{\prime} 28^{\prime \prime}$ & $\begin{array}{l}\text { Head of Lefaga Bay, S coast, boulder } \\
\text { in creek }\end{array}$ \\
\hline & UP25 & 0 & & 3 & & $13^{\circ} 55^{\prime} 41^{\prime \prime}$ & 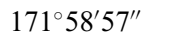 & ESE of Sama'i, SW coast \\
\hline $82-95$ & UP24 & $1.406,1.399$ & 6.278 & 71.1 & $2.58 \pm 0.03$ & $13^{\circ} 55^{\prime} 13^{\prime \prime}$ & $172^{\circ} 00^{\prime} 09^{\prime \prime}$ & E of Sama'i, SW coast, $\sim 40 \mathrm{~m}$ asl \\
\hline
\end{tabular}

$\lambda_{\mathrm{e}}=0.581 \times 10^{-10} \mathrm{a}^{-1} ; \lambda_{\mathrm{B}}=4.962 \times 10^{-10} \mathrm{a}^{-1} ;{ }^{40} \mathrm{~K} / \mathrm{K}=1.167 \times 10^{-4} \mathrm{~mol} / \mathrm{mol}$

${ }^{40} \mathrm{Ar}^{*}$ - radiogenic argon; Datum - WGS 84; asl - above sea level.

Phenocrystic phases, mainly olivine, removed from many samples.

All samples are basaltic, except for UP33, which is a trachyte.

Coordinates estimated from Google Earth. In general, Google Earth latitudes are $6 \pm 3$ seconds lower than those read from the map

(1:100,000 of Upolu, Department of Scientific and Industrial Research, New Zealand, 1958), whereas longitudes average $44 \pm 8$ seconds greater than those measured from the map. Presumably these differences relate to the use of different datums. Those in the table with an approximate sign before them were estimated from the map and adjusted to Google Earth coordinates, as there was partial cloud cover in the Google Earth image.

on the north side of Fagaloa Bay, just east of Fao, which rises to $820 \mathrm{~m}$ and is thought to be a trachyte intrusion (Natland \& Turner, 1985, p. 149). Three of the samples are from a track leading to Uafato near Cape Tagisia, the latter about $3.5 \mathrm{~km}$ to the east of Fagaloa Bay, whereas the remaining sample (82-104), a trachyte, is from a boulder at Ma'asina on the south side of Fagaloa Bay. These five ages are all significantly younger than ages measured on basalts to the north and northwest of Fagaloa Bay, previously discussed, and thus support the views of Natland (1980) and Natland \& Turner (1985) that these lavas are a younger infill of a caldera, subsequently eroded into a bay, similar to Pago Harbor on Tutuila (Stearns, 1944; McDougall, 1985). The caldera margin must be located not far from the head of Fagaloa Bay as older lavas were shown to occur on the road to the east of Fagaloa Saddle.

Two much younger ages of 1.37 and $1.38 \mathrm{Ma}(82-90$ (19), 82-91 (20)) from basalts near the southern limit of exposure of the Fagaloa Volcanics in the vicinity of Le Mafa at elevations of $200 \mathrm{~m}$ or more, and about $3.5 \mathrm{~km}$ southwest of the head of Fagaloa Bay, show that volcanism continued well into the Pleistocene, more than $0.3 \mathrm{Ma}$ younger than the lavas exposed around Fagaloa Bay.

In summary, taking the $\mathrm{K}-\mathrm{Ar}$ ages at face value, the Fagaloa Volcanics were erupted from at least as early as $2.78 \mathrm{Ma}$ ago in the Late Pliocene, until at least as late as $1.37 \mathrm{Ma}$ ago in the Pleistocene, and possibly even $0.93 \mathrm{Ma}$ ago (Workman et al. 2004), an interval of more than 1.8 Ma. Much of the shieldbuilding activity appears to have occurred between 2.8 and 2.1 Ma ago, with caldera formation and infilling centred on Fagaloa Bay at 1.86 to $1.70 \mathrm{Ma}$ ago, with evidence of volcanism continuing in the higher country around Le Mafa at about 1.37 Ma ago. To derive a mean age for the subaerial shield-building Fagaloa Volcanics, we can average all the ages reported here, giving a mean of $2.04 \pm 0.41 \mathrm{Ma}$, or if the two youngest ages are not included we obtain a mean of $2.15 \pm 0.35 \mathrm{Ma}(\mathrm{n}=$ $17)$, which is the value used subsequently.

Natland \& Turner (1985) published K-Ar whole rock ages on five samples from the Fagaloa Volcanics from Upolu, all falling between $1.54 \pm 0.05$ and 
$2.71 \pm 0.08 \mathrm{Ma}$, well within the range of ages presented in this contribution. Two of the lavas dated by Natland \& Turner (1985) were from the section at Cape Ulumau'u on the north coast, agreeing with one another at $2.71 \pm 0.08 \mathrm{Ma}$, a little older than the age of $2.51 \pm 0.03 \mathrm{Ma}$ obtained in this study on a basalt (82-72) from essentially the same locality. Further east near Tapuivi Point, Natland \& Turner (1985) obtained a K-Ar age of $2.45 \pm 0.07 \mathrm{Ma}$ on a basalt, somewhat older than the age of $2.16 \pm 0.03 \mathrm{Ma}$ reported here on sample 82-83 from a locality about $1 \mathrm{~km}$ to the west. Natland \& Turner (1985) obtained a $\mathrm{K}-\mathrm{Ar}$ age of $1.82 \pm 0.06 \mathrm{Ma}$ for a basalt near the southern limit of the Lufilufi Valley, and finally an age of $1.54 \pm 0.05 \mathrm{Ma}$ was given for a mugearite boulder from the south side of Fagaloa Bay, already discussed, somewhat younger than the age obtained here for a trachyte sample from nearby of $1.73 \pm 0.02 \mathrm{Ma}$. Thus, there is general agreement between the ages reported by Natland \& Turner (1985) for the Fagaloa Volcanics and those reported here, recognizing that in no case were identical samples likely to have been dated.

Tarling (1965) reported both normal and reverse palaeomagnetic polarity on lava samples collected from the Fagaloa Volcanics of Upolu. He surmised that the normal polarity samples were younger than those showing reverse polarity, probably belonging to the Brunhes Chron and less than about one million years old. Tarling (1965) assigned the reverse polarity lavas to the Matuyama Chron, which we now know extended from about 0.78 to $2.58 \mathrm{Ma}$ (Gradstein, Ogg \& Smith, 2004), but with shorter subchrons of normal polarity occurring within this interval. A number of lava flows sampled by Tarling (1965) that have normal polarity (sites 8,13 ) and reverse polarity (sites 6, $7,9,11$ ) are from localities (see D. H. Tarling, unpub. Ph.D. thesis, Australian National Univ. 1963) very close to samples dated here between 2.1 and 2.2 Ma, within the Matuyama Reversed Chron. The Réunion Subchron of normal polarity is within this age range (Kidane et al. 2007), so that it is suggested that these normal polarity lavas were erupted during the Réunion Subchron. Normal polarity measured in samples from Tarling's sites 13 and 14 (Tarling, 1965; D. H. Tarling, unpub. Ph.D. thesis, Australian National Univ. 1963) from lavas on the north coast just east of Apia near Lauli'i, close to sample 82115 of measured age $2.78 \pm 0.03 \mathrm{Ma}$, indicates that these samples were almost certainly erupted during the Gauss Normal Chron. Just south of Le Mafa at an altitude of about $260 \mathrm{~m}$, Tarling (1965; D. H. Tarling, unpub. Ph.D. thesis, Australian National Univ. 1963) found lavas of normal polarity (flows labelled 83, 84), whereas nearby lavas $(85,87)$ had reverse polarity. Two samples dated from this area $(82-90,82-91)$ gave ages of 1.37 and $1.38 \mathrm{Ma}$. At this age it would be expected that all lavas would have reverse polarity associated with the Matuyama Chron, so that it is difficult to account for the two normal polarity lavas sampled by Tarling in this general area. Perhaps the stratigraphy is more complex than has been assumed, possibly with the normal polarity lavas from older Fagaloa Volcanics in this area, covered by younger lavas.

Although samples were collected for possible $\mathrm{K}-\mathrm{Ar}$ dating from the Salani, Mulifanua and Lafaga volcanics on Upolu, no measurements were actually made, as similar rocks from Savai'i regarded as equivalents gave apparent ages of $\leq 0.22 \mathrm{Ma}$, in keeping with the views of Kear \& Wood (1959) that they were Middle Pleistocene or younger.

\section{Savai'i}

The island of Savai'i is separated from Upolu by only about $20 \mathrm{~km}$ of shallow seaway, and is by far the largest island in Samoa. Although both islands are regarded as separate volcanic culminations, at depth they coalesce into a large subsea structure (Kear \& Wood, 1959; Koppers et al. 2008) built upon seafloor more than $4000 \mathrm{~m}$ deep. Kear \& Wood (1959) thought that the quite youthful volcanism covering much of Savai'i was sufficiently similar to that on Upolu that a number of the same named formations have been used on both volcanic islands, and this also extends to the volcanics regarded as the oldest.

Savai' $i$ is located WNW of Upolu and is a much more equant island (Fig. 5). It is about $70 \times 40 \mathrm{~km}$ in size and rises to an altitude of $1858 \mathrm{~m}$ with a broad highland area. The main WNW-trending axis, essentially on strike with that on Upolu, is dotted with numerous local eruptive points and cones (Fig. 5), although these are rather more scattered and dispersed than those found along the axis of Upolu (Kear \& Wood, 1959). Much of the surface of Savai'i is covered by youthful basaltic volcanic rocks, and there are quite extensive areas adjacent to the northeast and north coasts underlain by historical Aopa Volcanics, the last of which erupted in 1911. Kear \& Wood (1959) suggested that volcanism commonly emanated from the main WNW-trending backbone of the island. There are numerous small normal faults, and one was recognized with a throw of about $150 \mathrm{~m}$, occurring along the north side of the crest of Savai'i, more or less parallel to the axial rift zone (Kear \& Wood, 1959). The general geology of the island is shown in Figure 5, after Kear \& Wood (1959), who identified a relatively small area in the north between Sāfotu and Fagamolo, drained by the Vaipouli River, as underlain by basalts that are termed the Fagaloa Volcanics. A small area in the headwaters of the Vanu River, draining to the south coast, also was mapped as Fagaloa Volcanics. The bulk of the island was mapped as Salani, Mulifanua, Puapua volcanics and the historical Aopa Volcanics, based mainly on geomorphological appearance.

Samples for possible $\mathrm{K}-\mathrm{Ar}$ dating were collected from the volcanic rocks mapped as Fagaloa Volcanics in the northern part of Savai'i, together with a number of basalts from localities in the Salani and Mulifanua 
Table 3. Potassium-argon ages on whole rock basalt samples from Savai'i, Western Samoa

\begin{tabular}{|c|c|c|c|c|c|c|c|c|}
\hline $\begin{array}{l}\text { Sample } \\
\text { number }\end{array}$ & $\begin{array}{l}\text { Field } \\
\text { number }\end{array}$ & K wt \% & $\begin{array}{l}{ }^{40} \mathrm{Ar}^{*} \\
10^{-12} \\
\mathrm{~mol} / \mathrm{g}\end{array}$ & $\%{ }^{40} \mathrm{Ar}^{*}$ & $\begin{array}{l}\text { Calculated age } \\
\mathrm{Ma} \pm 1 \text { s.d. }\end{array}$ & Latitude S & Longitude W & Locality \\
\hline \multicolumn{9}{|c|}{ Mulifanua Volcanics } \\
\hline $82-143$ & SA17 & $1.096,1.094$ & 0.052 & 1.3 & $0.03 \pm 0.01$ & $13^{\circ} 30^{\prime} 56^{\prime \prime}$ & $172^{\circ} 41^{\prime} 38^{\prime \prime}$ & Sataua, $N$ coast, thin flow \\
\hline $82-142$ & SA16 & $1.892,1.893$ & 0.102 & 1.3 & $0.03 \pm 0.01$ & $13^{\circ} 38^{\prime} 39^{\prime \prime}$ & $172^{\circ} 40^{\prime} 02^{\prime \prime}$ & Near Fagafau, SW coast, $5 \mathrm{~m}$ flow \\
\hline $82-141$ & SA15 & $1.621,1.628$ & 0.616 & 8.7 & $0.22 \pm 0.01$ & $13^{\circ} 42^{\prime} 13^{\prime \prime}$ & $172^{\circ} 36^{\prime} 20^{\prime \prime}$ & Near Foailuga, SW coast, $\sim 5 \mathrm{~m}$ flow \\
\hline \multicolumn{9}{|c|}{ Salani Volcanics } \\
\hline $82-129$ & SA3 & $1.225,1.227$ & 0.445 & 9.5 & $0.21 \pm 0.01$ & $13^{\circ} 30^{\prime} 46^{\prime \prime}$ & $172^{\circ} 18^{\prime} 07^{\prime \prime}$ & Mali'oli'o River, NE coast, $\sim 10 \mathrm{~m}$ flow \\
\hline $82-127$ & SA1 & $1.754,1.755$ & 0.336 & 8.0 & $0.11 \pm 0.01$ & $13^{\circ} 38^{\prime} 48^{\prime \prime}$ & $172^{\circ} 14^{\prime} 59^{\prime \prime}$ & Vaiola, near $E$ coast, thin flow \\
\hline $82-140$ & SA14 & $0.749,0.750$ & 0.118 & 2.5 & $0.09 \pm 0.01$ & $13^{\circ} 44^{\prime} 53^{\prime \prime}$ & $172^{\circ} 19^{\prime} 01^{\prime \prime}$ & Near $\mathrm{S}$ coast, thin flow \\
\hline \multicolumn{9}{|c|}{ 'Fagaloa' Volcanics } \\
\hline $82-130$ & SA4A & $1.509,1.510$ & 0.976 & 20.0 & $0.37 \pm 0.01$ & $13^{\circ} 26^{\prime} 48^{\prime \prime}$ & $172^{\circ} 23^{\prime} 24^{\prime \prime}$ & $\mathrm{N}$ coast, $\sim 10 \mathrm{~m}$ flow \\
\hline $82-131$ & SA5 & $1.524,1.528$ & 1.031 & 19.2 & $0.39 \pm 0.01$ & $13^{\circ} 26^{\prime} 48^{\prime \prime}$ & $172^{\circ} 23^{\prime} 24^{\prime \prime}$ & Same flow as SA4A, $1 \mathrm{~km}$ E of Sāfotu \\
\hline $82-132$ & SA6 & $1.438,1.437$ & 1.043 & 27.5 & $0.42 \pm$ & $13^{\circ} 26^{\prime} 47^{\prime \prime}$ & $172^{\circ} 23^{\prime} 16^{\prime \prime}$ & Just $\mathrm{E}$ of SA5, $\sim 15 \mathrm{~m}$ flow \\
\hline $82-137$ & SA11 & $1.161,1.157$ & 0.843 & 20.3 & $0.42 \pm 0.01$ & $13^{\circ} 27^{\prime} 48^{\prime \prime}$ & $172^{\circ} 22^{\prime} 13^{\prime \prime}$ & Viapouli River, altitude $\sim 70 \mathrm{~m}$ \\
\hline $82-135$ & SA9 & $1.546,1.548$ & 0.886 & 18.4 & $0.33 \pm 0.01$ & $13^{\circ} 28^{\prime} 32^{\prime \prime}$ & $172^{\circ} 23^{\prime} 47^{\prime \prime}$ & E of Paia, altitude $\sim 120 \mathrm{~m}$ \\
\hline $82-133$ & SA7 & $1.207,1.210$ & 0.665 & 18.3 & $0.32 \pm 0.01$ & $13^{\circ} 28^{\prime} 58^{\prime \prime}$ & $172^{\circ} 24^{\prime} 00^{\prime \prime}$ & $\sim 4 \mathrm{~km} \mathrm{~S}$ of Sāfotu, altitude $\sim 200 \mathrm{~m}$ \\
\hline $82-134$ & SA8 & $0.792,0.793$ & 0.498 & 11.1 & $0.36 \pm 0.01$ & $13^{\circ} 29^{\prime} 11^{\prime \prime}$ & $172^{\circ} 23^{\prime} 58^{\prime \prime}$ & $\sim 4.5 \mathrm{~km} \mathrm{~S}$ of Sāfotu, altitude $\sim 300 \mathrm{~m}$ \\
\hline
\end{tabular}

$\lambda_{\mathrm{e}}=0.581 \times 10^{-10} \mathrm{a}^{-1} ; \lambda_{\beta}=4.962 \times 10^{-10} \mathrm{a}^{-1} ;{ }^{40} \mathrm{~K} / \mathrm{K}=1.167 \times 10^{-4} \mathrm{~mol} / \mathrm{mol}$

${ }^{40} \mathrm{Ar}^{*}$ - radiogenic argon; Datum -WGS 84

Phenocrystic phases, mainly olivine, removed from each sample.

All coordinates are best estimates from Google Earth but identification of actual sample sites was often difficult from the images.

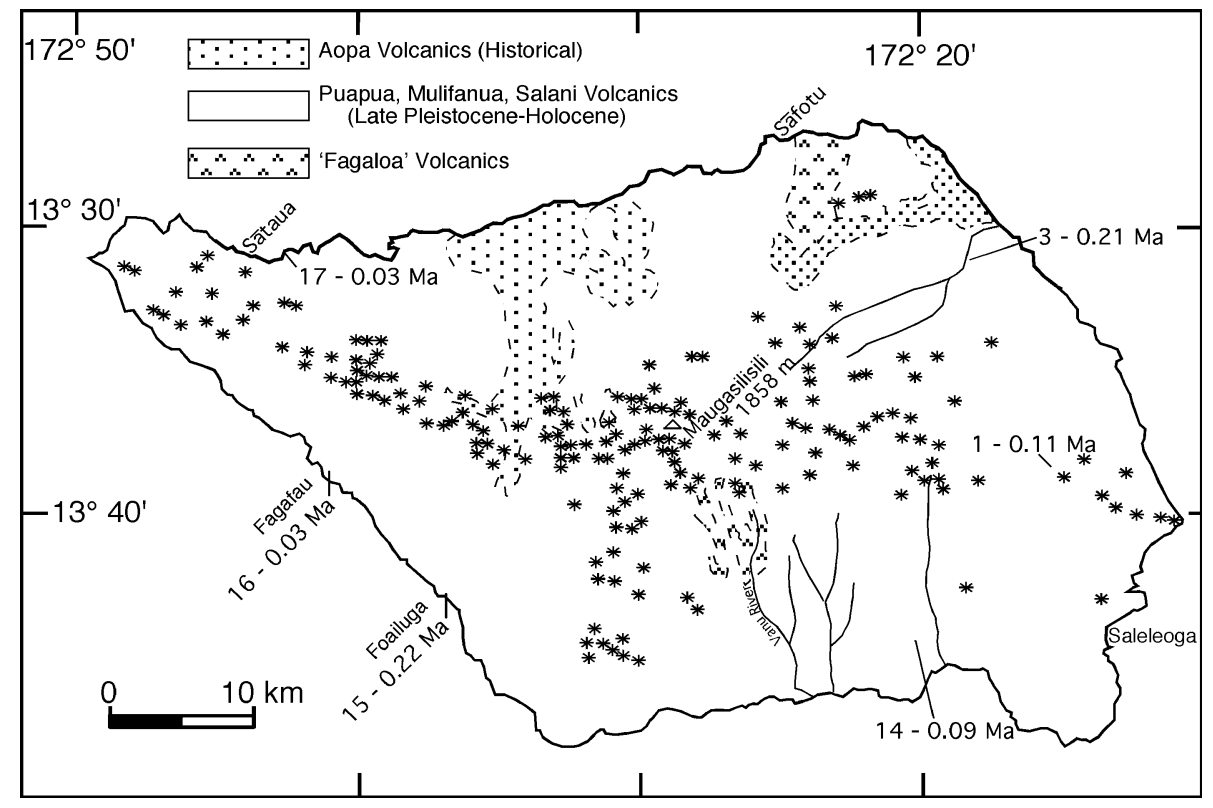

Figure 5. Simplified geology of Savai'i, after Kear \& Wood (1959). Locations of relatively youthful centres of eruption are distributed mainly along the major WNW-ESE axis, and are shown by stars. The location of each dated sample and its K-Ar age is shown for the younger samples; see Table 3 for the data.

volcanics (Fig. 5). The $\mathrm{K}-\mathrm{Ar}$ results are listed in Table 3. The seven samples collected from the area mapped as Fagaloa Volcanics, adjacent to the north coast, gave $\mathrm{K}-\mathrm{Ar}$ ages in the relatively narrow range of 0.32 to $0.42 \mathrm{Ma}$, averaging $0.37 \pm 0.04 \mathrm{Ma}$, clearly indicating that these basaltic lavas were erupted in the Middle Pleistocene in the Brunhes Chron, in keeping with the normal palaeomagnetic polarity for two samples from the same sequence on the coast near Sāfotu, reported by Tarling (1965), and the normal polarity given by Keating (1985) for at least five coastal sites in the same volcanic rocks near Săfotu. Two basalts, 82-130 (4A) and 82-131 (5), from the same lava flow on the coast just east of Săfotu gave similar ages of $0.37 \pm 0.01$ and $0.39 \pm 0.01 \mathrm{Ma}$, respectively, and another sample from a lava flow on a headland about $300 \mathrm{~m}$ further east, yielded a slightly older apparent age of $0.42 \pm 0.01 \mathrm{Ma}$ (Table 3; Fig. 6). Sample 82-137 (11) was collected from a boulder in the Vaipouli River (Fig. 6) just above a small waterfall in a nearly horizontal lava flow. It yielded a $\mathrm{K}-\mathrm{Ar}$ age of $0.42 \mathrm{Ma}$, similar to the ages found for lavas near Sāfotu. The good agreement between these ages provides considerable confidence in their veracity. These flows are essentially horizontal and are characterized by the presence of small angular olivinerich nodules as well as some olivine phenocrysts, which were largely removed prior to dating. 


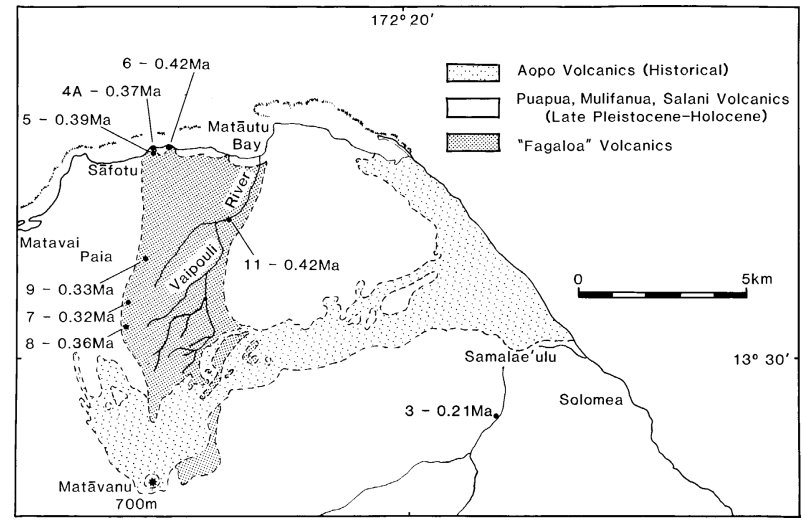

Figure 6. Simplified geological map of the northeastern part of Savai'i, after Kear \& Wood (1959). The location and K-Ar age result for each of the samples from the rocks in the Vaipouli River area are shown; see Table 3 for data.

Three additional samples of basalt were collected inland from Sāfotu (Fig. 6). Owing to poor outcrop, each of the samples was collected from a locally derived boulder. The measured $\mathrm{K}-\mathrm{Ar}$ ages range from 0.32 to $0.36 \mathrm{Ma}$ (Table 3 ), similar to but slightly younger than those from the north coast. The three samples show a range of potassium contents from 0.79 to $1.55 \%$, and were collected from localities at altitudes from about 120 to $300 \mathrm{~m}$. Sample 82-135 (9) was from a boulder at the foot of a waterfall in Vailolo Stream where it cuts through a scarp marking the western edge of this basalt sequence. From the ages it is clear that these volcanic rocks are much younger than the Fagaloa Volcanics on Upolu, so that an alternative name needs to be arrived at for these lavas. Workman et al. (2004) summarized ${ }^{40} \mathrm{Ar}-{ }^{39} \mathrm{Ar}$ step heating data for two samples of basalt from what they called the Manase Shield, which is the term they used for the lavas mapped as Fagaloa Volcanics south of Sāfotu on the north coast. Plateau ages of $0.24 \pm 0.05$ and $0.39 \pm 0.01$ Ma were obtained, quite similar to the $\mathrm{K}-\mathrm{Ar}$ ages reported here. A total fusion ${ }^{40} \mathrm{Ar}-{ }^{39} \mathrm{Ar}$ age of $2.05 \mathrm{Ma}$ also was reported by Workman et al. (2004) for a trachyte boulder collected from the lower Vanu River in the southern interior of Savai'i, from what was termed the Vanu River Shield, mapped as a limited exposure of shield volcanic rocks by Kear \& Wood (1959). On the basis of a single result, without any analytical and limited locality details, it is difficult to evaluate the reliability of the age, but it does suggest that shield lavas of considerably older age do underlie the youthful post-erosional volcanism that covers much of the island.

The Salani Volcanics, as mapped on Savai'i, were regarded by Kear \& Wood (1959) as Middle to Late Pleistocene, no older than the penultimate glaciation to last interglacial. Three samples mapped as Salani Volcanics that were dated were from the eastern half of the island (Fig. 5), and gave apparent ages of $0.09 \pm 0.01$ to $0.21 \pm 0.01 \mathrm{Ma}$ (Table 3), quite consistent with the broad estimates of age given by Kear \& Wood (1959).
Similarly, dating was attempted on three basalt samples collected from areas mapped as Mulifanua Volcanics (Fig. 5). Two of the samples, one from near Fagafau on the southwest coast (82-142 (16)), and the other from Sātaua on the north coast (82-143 (17)) yielded very young apparent ages of about $0.03 \mathrm{Ma}$ with large uncertainties because only about $1 \%$ of the argon was identified as radiogenic. Kear \& Wood (1959) suggested that the Mulifanua Volcanics were erupted during about last glaciation times, and the youthful ages are consistent with this view. A third sample mapped as Mulifanua Volcanics (82-141 (15)) from the southwest coast near Foailuga gave a $\mathrm{K}$ Ar age of $0.22 \pm 0.01 \mathrm{Ma}$. The age suggests that it might actually be included with the Salani Volcanics. Even younger basalts, including the historical Aopa Volcanics, are widespread on Savai'i.

It is obvious that the bulk of the island of Savai'i is covered by youthful basaltic volcanism extending to even historic times. The main question is whether this volcanism is a veneer that actually buries shieldbuilding lavas of much greater age. The volcanic rocks regarded by Kear \& Wood (1959) as possible shieldbuilding lavas adjacent to the north coast are shown to be also quite young, $<0.4 \mathrm{Ma}$, although there is some evidence of older material (c. $2 \mathrm{Ma}$ ) in the gorge of the Vanu River near the centre of the island. Further study of rocks from this gorge should be a high priority. For the hotspot model to be shown to be a viable explanation for much of the volcanism in the Samoan chain, the expectation would be that the shield-building phase should be significantly older than that exhibited on Upolu, so ages of $4 \mathrm{Ma}$ or more, now shown to be the case for rocks dredged from the submarine flanks of Savai'i (Koppers et al. 2008), are more in keeping with a hotspot model.

\section{Volcanic migration}

Figure 7 is a plot of average measured age for the subaerial shield-building volcanism versus distance from the active volcanic seamount, Vailulu'u (Hart et al. 2004) to Upolu, projected onto a common line. Results from Savai'i are also plotted, using the consistent ages of $5.02 \pm 0.03$ Ma obtained by Koppers et al. (2008) on samples from dredging of the deep submarine base of Savai'i. The six points plotted in Figure 7 yield a relatively poorly fitting linear array $\left(\mathrm{r}^{2}=0.834\right)$, with a slope reflecting the migration rate of the volcanism of $72.1( \pm 14.3) \mathrm{mm} \mathrm{a}^{-1}$, and an intercept on the distance axis of $50.7 \pm 32.8 \mathrm{~km}$, just to the west of Vailulu'u. As the spread in the ages associated with each volcano is not taken into account in the regression, the errors are probably underestimated. These data indicate that the focus of shield-building volcanism has moved in a general ESE direction over the last $5 \mathrm{Ma}$ by about $365 \mathrm{~km}$ in a systematic manner. Noting again that the current GPS measured rate of Pacific Plate motion in the Samoa Islands is $71.8( \pm 0.7) \mathrm{mm} \mathrm{a}^{-1}$ at $\mathrm{N} 64^{\circ} \mathrm{W}$ (Beavan 


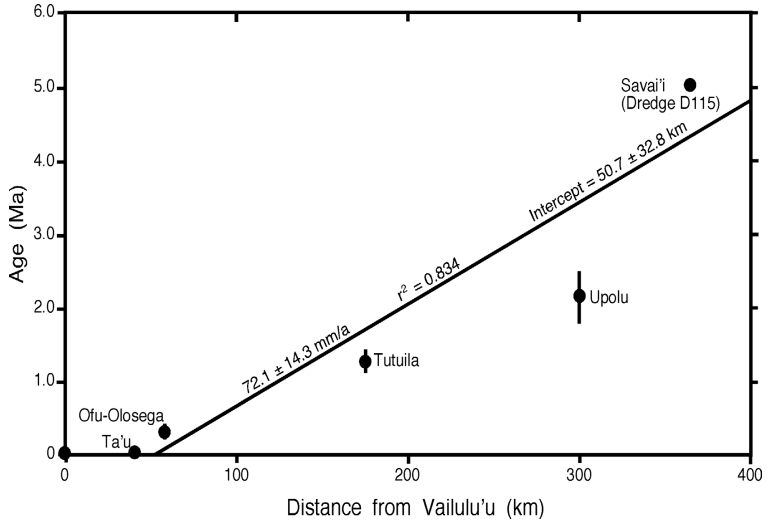

Figure 7. Average age for the subaerial shield-building volcanism for Ta'u, Ofu/Olosega, Tutuila and Upolu, and the average age determined on samples from dredge D115 from the submarine edifice of Savai'i (cf. Koppers et al. 2008) in the Samoa Islands plotted against distance from Vailulu'u, showing that there is reasonable fit to a straight line, indicating a migration rate of the volcanism to the ESE occurred at $72.1 \pm 14.3 \mathrm{~mm} \mathrm{a}^{-1}$. Error bar for the mean age for each island is the standard deviation of the age population used in the calculation of the mean age. Note that Vailulu'u is plotted at zero, following Hart et al. (2004).

et al. 2002), the average rate of volcanic migration is remarkably close to this velocity. Thus, the propagation direction and rate of the volcanism is consistent with plate motion over a magma source below the rigid surface plate.

However, it should be noted that this result is critically dependent upon using the older age for the rocks dredged from the submarine flanks of Savai'i. Thus, if only ages on the subaerial volcanics from Ta'u, Ofu/Olosega, Tutuila and Upolu are utilized, regression analysis indicates a reasonably good fit $\left(\mathrm{r}^{2}=0.939\right)$, with a slope reflecting a migration rate of the volcanism of $130.1( \pm 8.1) \mathrm{mm} \mathrm{a}^{-1}$, and an intercept on the distance axis of $15.5( \pm 9.1) \mathrm{km}$, very much exceeding the plate motion rate determined from GPS measurements. It thus seems likely that volcanic migration rates determined from ages of subaerial lavas, regarded as shield-building, may significantly overestimate the rate determined from rocks deeper in the individual edifices (see below).

The abundance of youthful basaltic volcanism on Upolu, and particularly on Savai'i, may reflect the effects of flexure and faulting of the Pacific Plate as it interacts with the Tonga Trench and the Australian Plate boundary, as previously argued by Hawkins \& Natland (1975). This youthful volcanism is regarded by Hawkins \& Natland (1975) as typically post-shieldbuilding in character, dominated by basaltic volcanism that is undersaturated (alkaline) rather than transitional or tholeiitic (cf. Natland \& Turner, 1985), which is more typical of the shield-building phase of some of the volcanoes. Hawkins \& Natland (1975) suggested that even the shield-building volcanism in the Samoa Islands is generally alkaline and also might well be related to the proximity to the Tonga Trench. However,

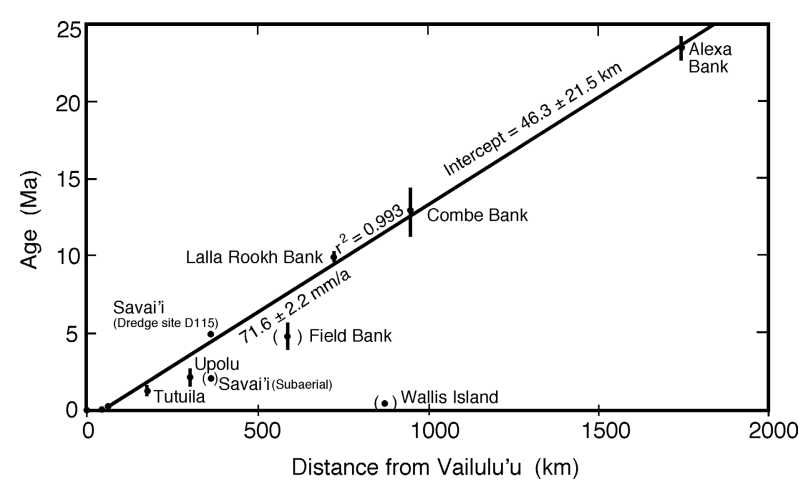

Figure 8. Regression of selected age data versus distance from Vailulu'u in the extended Samoa Island chain, including several seamounts. The results from Field Bank, and Wallis Island are excluded from the calculations, see text.

the possibility remains that the shield-building lavas are produced from an underlying hotspot source and that it is only the younger lavas that are related to sources in the mantle influenced by the flexure of the Pacific Plate as it approaches the Australian Plate, or because of proximity to the Vitiaz Lineament, regarded as a transform between the Pacific Plate and the Australian Plate (Hart et al. 2004).

Duncan (1985) showed that if the K-Ar and ${ }^{40} \mathrm{Ar}-$ ${ }^{39} \mathrm{Ar}$ total fusion ages from dredged samples from volcanic seamounts to the WNW of Savai'i, particularly Field, Lalla Rookh and Combe are included, an overall average rate of volcanic migration of about $77( \pm$ 25) $\mathrm{mm} \mathrm{a}^{-1}$ is obtained (see caption to fig. 2 of Duncan, 1985), very similar to the current Pacific Plate velocity and with the NUVEL-1A and REVEL plate models (DeMets \& Dixon, 1999; Sella, Dixon \& Mao, 2002), and thus consistent with an essentially fixed magma source in the mantle beneath the plate. Using Vailulu'u as the zero point, and including age data from Lalla Rookh, Combe and Alexa banks or seamounts, linear regression gives a good fit to the data with an $\mathrm{r}^{2}$ of 0.993 (Fig. 8), yielding a migration rate of $71.6( \pm 2.2) \mathrm{mm} \mathrm{a}^{-1}$, in excellent agreement with the current plate motion and the NUVEL-1A and REVEL plate motion models. If the data from Field Bank are also included, the average of the $\mathrm{K}-$ $\mathrm{Ar}$ and ${ }^{40} \mathrm{Ar}-{ }^{39} \mathrm{Ar}$ total fusion ages for sample RD12 at $4.80 \pm 0.85 \mathrm{Ma}$ (Duncan, 1985), the regression changes only marginally $\left(\mathrm{r}^{2}=0.971\right.$, slope $=70.7 \pm$ $4.6 \mathrm{~mm} \mathrm{a}^{-1}$, intercept $\left.=84.1 \pm 44.5 \mathrm{~km}\right)$.

The data used, apart from the ages from the subaerial Samoa Islands (excluding Savai'i), are the average of the ${ }^{40} \mathrm{Ar}-{ }^{39} \mathrm{Ar}$ ages for samples from dredge D115 south of Savai'i (Koppers et al. 2008), the average of the KAr and ${ }^{40} \mathrm{Ar}-{ }^{39} \mathrm{Ar}$ total fusion ages for sample RD3-16 from Lalla Rookh Bank of 9.9 $\pm 0.3 \mathrm{Ma}$ from Duncan (1985), about $723 \mathrm{~km}$ from Vailulu'u, a similar average for Combe Bank on sample RD7-11 (Duncan, 1985), together with a weighted ${ }^{40} \mathrm{Ar}-{ }^{39} \mathrm{Ar}$ plateau age of $11.1 \pm 0.1 \mathrm{Ma}$ on RD7-100 from Hart et al. (2004) yielding a mean age of $12.9 \pm 1.6 \mathrm{Ma}\left(12.702^{\circ} \mathrm{S}\right.$, $\left.177.685^{\circ} \mathrm{W}\right), 723 \mathrm{~km}$ from Vailulu'u, and the average 
weighted mean plateau ages for samples RD14-19 and $14-100$ at $23.4 \pm 0.7$ Ma for Alexa Bank $\left(11.685^{\circ} \mathrm{S}\right.$, $184.953^{\circ} \mathrm{W}$ ), from Hart et al. (2004), $1745 \mathrm{~km}$ from Vailulu'u. Younger ages given by Duncan (1985) for Wallis Island (see also Price et al. 1991), the young age for another sample from Lalla Rookh Bank (Hart et al. 2004), and the significantly older age on sample RD12-1 from northeast of Nurakita Bank $\left(\sim 10.02^{\circ} \mathrm{S}, 179.41^{\circ} \mathrm{W}\right)$ were not included, following Duncan (1985). Clearly the large distances of these seamounts from Vailulu'u, up to $1745 \mathrm{~km}$, and their ages fitting well with the fixed or nearly fixed hotspot model, have a profound influence on the regressions. Yet where it is possible to measure ages directly on subaerial shield-building volcanic rocks we obtain much higher apparent volcanic migration rates.

It is noteworthy that the rate of migration of volcanism determined by direct dating of subaerial shield-building lavas from a number of other island chains on the Pacific Plate covering the last $5 \mathrm{Ma}$ (Hawaii, Society, Austral and Marquesas islands) also exceed the current GPS measured plate motions at these localities, as well as the plate motions described under NUVEL-1A and REVEL, by between 30 and $55 \%$. Except for the Vailulu'u to Upolu sector of the Samoa Islands, which suggests the volcanic migration rate is about $80 \%$ greater than the plate motion in the opposite direction, the other island chains considered yield reasonably concordant and congruent volcanic migration rates and directions among themselves (Duncan \& McDougall, 1976; McDougall \& Duncan, 1980), which we previously interpreted as indicating that the magma sources (hotspots) were essentially fixed in the mantle below the Pacific Plate relative to one another.

From these data, the comparisons between the plate models as well as current plate motions determined by GPS measurements for the Pacific Plate generally are within $50 \%$ of the volcanic migration rates, suggesting that the surface volcanoes are at best only approximate geological trackers of plate motions. Indeed, the resolution now obtainable from present day GPS measurements may be such that it is beginning to be possible to separate plate motions and return flow in the mantle source regions for the volcanism, as well as indicating that ages on deeper rocks from the volcanic edifices are likely to provide more robust estimates of rates of volcanic migration in island chains. These issues have been discussed in detail by many workers; for example, see Morgan \& Phipps Morgan (2007). However, it is emphasized that, especially on fastmoving plates, the linear volcanic chains provide some information on rates of plate motion and direction to the first order. Apart from examples on the Pacific Plate, the concurrence of the modelling and the measured volcanic migration in the Tasmantid Seamounts on the Australian Plate as it moves to the NNE is another very good example of apparent concordance (McDougall \& Duncan, 1988; Gaina, Müller \& Cande, 2000).
Acknowledgements. The Government of Samoa is thanked for permission to collect samples from Upolu and Savai'i. Special thanks to Robyn Maier for her assistance in processing samples in the K-Ar laboratory. Paul Tregoning, Bob Duncan and Anthony Koppers kindly made helpful comments on draft versions of this manuscript. Reviewers are thanked for additional useful comments.

\section{References}

Beavan, J., Tregoning, P., Bevis, M., Kato, T. \& MEERTENS, C. 2002. Motion and rigidity of the Pacific Plate and implications for plate boundary deformation. Journal of Geophysical Research 107, doi: 10.1029/2001JB000282, 15 pp.

ChuBB, L. J. 1957. The pattern of some Pacific island chains. Geological Magazine 94, 221-8.

DANA, J. D. 1849. Geology. United States Exploring Expedition during the years 1838-1842 under the command of Charles Wilkes, U. S. N., 10, 307-36. Philadelphia: C. Sherman.

DALY, R. A. 1924. The geology of American Samoa. Carnegie Institution of Washington Publication 340, 95 143.

DEMETS, C. \& DiXON, T. H. 1999. New kinematic models for Pacific-North America motion from 3 Ma to present; I: Evidence for steady motion and biases in the NUVEL1A model. Geophysical Research Letters 26, 1921-4.

DUNCAN, R. A. 1985. Radiometric ages from volcanic rocks along the New Hebrides-Samoa lineament. In Geological Investigations of the Northern Melanesian Borderland (ed. T. M. Brocher), pp. 67-76. CircumPacific Council for Energy and Mineral Resources Earth Science Series 3. Houston, Texas: Circum-Pacific Council for Energy and Mineral Resources.

Duncan, R. A. \& MCDougall, I. 1976. Linear volcanism in French Polynesia. Journal of Volcanology and Geothermal Research 1, 197-227.

FRIEDLÄNDER, I. 1910. Beiträge zur Geologie der Samoainseln. Abhandlungen der bayerischen Academie der Wissenschaften, Mathematisch-physikalische Klasse 24, 507-41.

Gaina, C., Müller, R. D. \& CAnde, S. C. 2000. Absolute plate motion, mantle flow, and volcanism at the boundary between the Pacific and Indian Ocean mantle domains since 90 Ma. In The History and Dynamics of Global Plate Motions (eds M. A. Richards, R. G. Gordon \& R. D. van der Hilst), pp. 189-210. American Geophysical Union Geophysical Monograph no. 121.

Gradstein, F., OgG, J. \& SMith, A. 2004. A Geologic Time Scale 2004. Cambridge: Cambridge University Press.

Hart, S. R., Staudigel, H., Koppers, A. A. P., Blusztajn, J., BAKER, E. T., WORKMAN, R., JACKSON, M., HAURI, E., Kurz, M., Sims, K., Fornari, D., SAal, A. \& LYONS, S. 2000. Vailulu'u undersea volcano: The new Samoa. Geochemistry Geophysics Geosystems 1, doi:2000GC000108, 13 pp.

Hart, S. R., COEtzee, M., Workman, R. K., Blusztajn, J., Johnson, K. T. M., Sinton, J. M., STEINBERGER, B. \& HaWkINS, J. W. 2004. Genesis of the Western Samoa seamount province: age, geochemical fingerprint and tectonics. Earth and Planetary Science Letters 227, 37 56.

HaWkins, J. W. \& NATLAND, J. H. 1975. Nephelinites and basanites of the Samoan linear volcanic chain: Their possible tectonic significance. Earth and Planetary Science Letters 24, 427-39. 
JaCKSON, M. G., HART, S. R., Koppers, A. A. P., StaUdigel, H., Konter, J., BluszTajn, J., Kurz, M. \& Russell, J. A. 2007. The return of subducted continental crust in Samoan lavas. Nature 448, 684-7.

JENSEN, H. I. 1907. The geology of Samoa, and the eruptions in Savai'i. Proceedings of the Linnean Society of New South Wales 31, 641-72.

KeAR, D. \& WooD, B. L. 1959. The Geology and Hydrology of Western Samoa. New Zealand Geological Survey Bulletin n.s. 63, 92 pp.

Keating, B. 1985. Paleomagnetic studies of the Samoan Islands: Results from the islands of Tutuila and Savaii. In Geological Investigations of the Northern Melanesian Borderland (ed. T. M. Brocher), pp. 187-99. CircumPacific Council for Energy and Mineral Resources Earth Science Series 3. Houston, Texas, Circum-Pacific Council for Energy and Mineral Resources.

KeAting, B. H. 1992. The geology of the Samoan Islands. In Geology and Offshore Mineral Resources of the Central Pacific Basin (eds B. H. Keating \& B. R. Bolton), pp. 127-78. Circum-Pacific Council for Energy and Mineral Resources Earth Science Series 14. New York: Springer-Verlag.

KidANe, T., OtofuJi, Y.-I., Brown, F. H., TAKemoto, K. \& Eshete, G. 2007. Two normal paleomagnetic polarity intervals in the lower Matuyama Chron recorded in the Shungura Formation (Omo Valley, Southwest Ethiopia). Earth and Planetary Science Letters 262, 240-56.

Koppers, A. A. P., RuSSEll, J. A., JACKSON, M. G., KONTER, J., STAUDigEL, H. \& HART, S. R. 2008. Samoa reinstated as a primary hotspot trail. Geology 36, 435-8.

Matsuda, J.-I., Notsu, K., OKano, J., Yaskawa, K. \& Chungue, L. 1984. Geochemical implications from $\mathrm{Sr}$ isotopes and $\mathrm{K}-\mathrm{Ar}$ age determinations for the CookAustral islands chain. Tectonophysics 104, 145-54.

MCDOUgall, I. 1985. Age and evolution of the volcanoes of Tutuila, American Samoa. Pacific Science 39, 311-20.

MCDOUGall, I. \& DunCAN, R. A. 1980. Linear volcanic chains - Recording plate motions? Tectonophysics $\mathbf{6 3}$, 275-95.

McDougall, I. \& Duncan, R. A. 1988. Age progressive volcanism in the Tasmantid Seamounts. Earth and Planetary Science Letters 89, 207-220.

MCDOUGALL, I. \& FEIBEL, C. S. 1999. Numerical age control for the Miocene-Pliocene succession at Lothagam, a hominoid-bearing sequence in the northern Kenya Rift. Journal of the Geological Society, London 156, 731-45.

Montelli, R., Nolet, G., Dahlen, F. A., Masters, G., ENGDAHL, E. R. \& HUNG, S.-H. 2004. Finite-frequency tomography reveals a variety of plumes in the mantle. Science 303, 338-43.

MORGAN, W. J. 1971. Convection plumes in the lower mantle. Nature 230, 42-3.
Morgan, W. J. \& Phipps Morgan, J. 2007. Plate velocities in the hotspot reference frame. In Plates, Plumes, and Planetary Processes (eds G. R. Foulger \& D. M. Jurdy), pp. 65-78. Geological Society of America, Special Paper no. 430.

NATLAND, J. H. 1980. The progression of volcanism in the Samoan linear volcanic chain. American Journal of Science 280A, 709-35.

NATLAND, J. H. \& TURNER, D. L. 1985. Age progression and petrological development of Samoan shield volcanoes: Evidence from $\mathrm{K}-\mathrm{Ar}$ ages, lava compositions, and mineral studies. In Geological Investigations of the Northern Melanesian Borderland (ed. T. M. Brocher), pp. 139-71. Circum-Pacific Council for Energy and Mineral Resources Earth Science Series 3. Houston, Texas, Circum-Pacific Council for Energy and Mineral Resources.

Price, R. C., Maillet, P., McDougall, I. \& Dupont, J. 1991. The geochemistry of basalts from the Wallis Islands, Northern Melanesian Borderland: Evidence for a lithospheric origin for Samoan-type basaltic magmas? Journal of Volcanology and Geothermal Research 45, 267-88.

Sella, G. F., DiXon, T. H. \& MAO, A. 2002. REVEL: A model for Recent plate velocities from space geodesy. Journal of Geophysical Research 107, doi: 10.1029/2000JB000033, 30 pp.

SteARnS, H. T. 1944. Geology of the Samoan Islands. Bulletin of the Geological Society of America 55, 1279 1331.

STEIGER, R. H. \& JÄGER, E. 1977. Subcommission on geochronology: Convention on the use of decay constsnts in geo- and cosmochronology. Earth and Planetary Science Letters 36, 359-62.

Stice, G. D. \& McCoY, F. W. JR. 1968. The geology of the Manu'a Islands, Samoa. Pacific Science 22, 427-57.

TARLING, D. H. 1965. The palaeomagnetism of the Samoan and Tongan Islands. Geophysical Journal of the Royal Astronomical Society 10, 497-513.

Thomson, J. A. 1921. The geology of Western Samoa. New Zealand Journal of Science and Technology 4, 49-66.

WILSON, J. T. 1963. A possible origin of the Hawaiian Islands. Canadian Journal of Physics 41, 863-70.

WORKMAN, R. K., HART, S. R., JaCKSON, M., REgElous, M., FARley, K. A., Blusztajn, J., Kurz, M. \& STAUDIGEL, H. 2004. Recycled metasomatized lithosphere as the origin of the Enriched Mantle II (EM2) end-member: Evidence from the Samoan volcanic chain. Geochemistry Geophysics Geosystems 5, doi: 10.1029/2003GC000623, 44 pp.

Wright, E. \& WhiTE, W. M. 1986/87. The origin of Samoa: new evidence from $\mathrm{Sr}, \mathrm{Nd}$ and $\mathrm{Pb}$ isotopes. Earth and Planetary Science Letters 81, 151-62. 